نشريه تحقيقات كاربردى علوم جغرافيايى، سال بيستم، شماره هV، تابستان 99

تعيين تقويم زراعى كاشت ذرت با استفاده از آزمون T مشاهدهاى و يهنهـ-

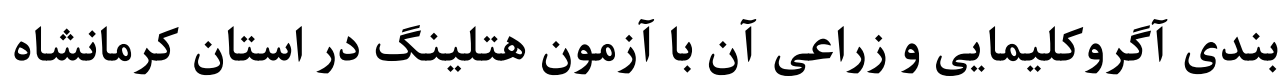

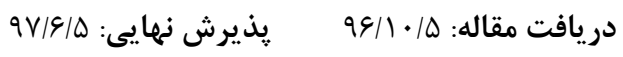 \\ صفحات: ro-rV \\ بهروز سبحانى: دانشيار اقليهشناسى، دانشكاه محقق اردبيلى، اردبيل، ايران.'
}

Email: sobhaniardabil@gmail.com

وحيد صفريان زنغير: دانشجوى دكترى رشته جغرافياى طبيعى، اقليمشناسى، دانشعاه محقق اردبيلى، اردبيل، ايران.

Email: v.Safarian@uma.ac.ir

اخضر كرمى: دانش آموخته، كارشناسى ارشد، رشته اقليم شناسى، دانشعاه محقق اردبيلى، اردبيل، ايران.

Email: a.karami@uma.ac.ir

جكيده

محدوديتها و مرزهاى توليد محصولات كشاورزى وابسته به شرايط اقليمى است. آب و هوا يكى از مهرهمترين

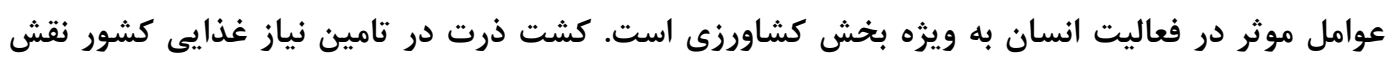

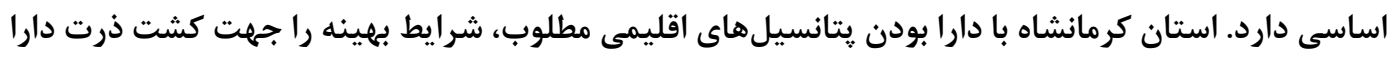

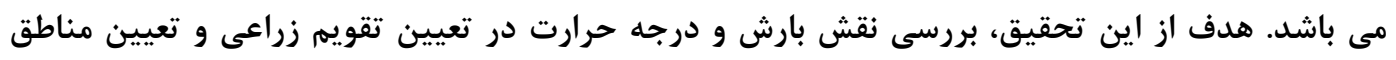

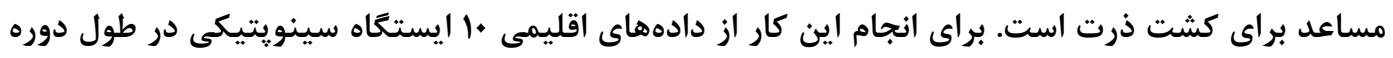

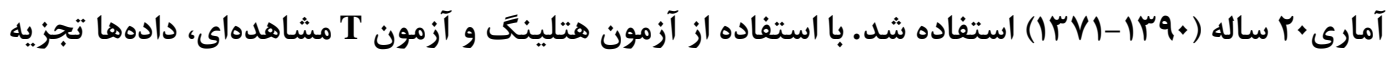

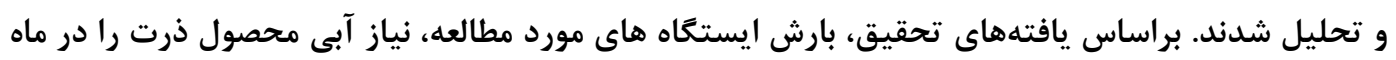

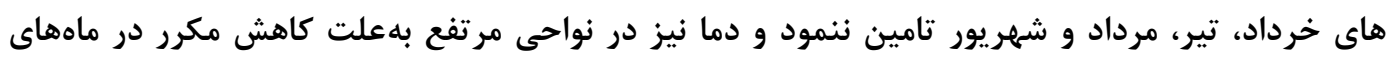

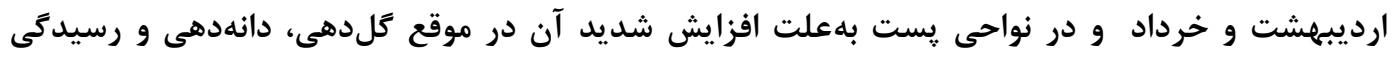

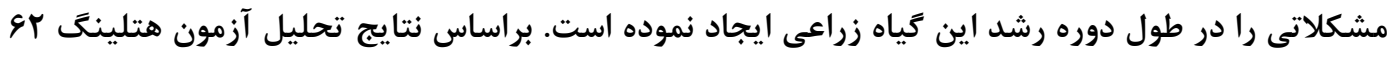

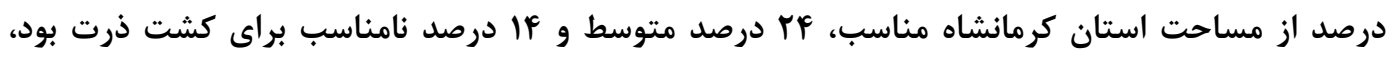

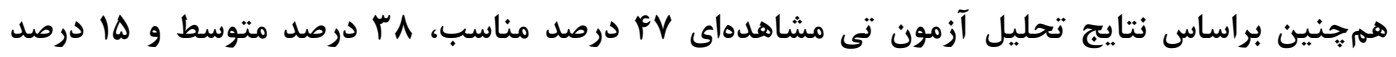

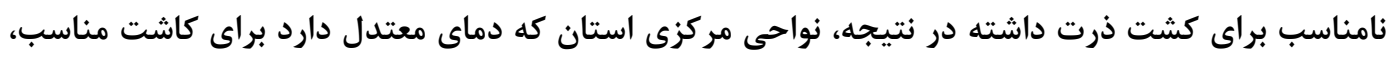

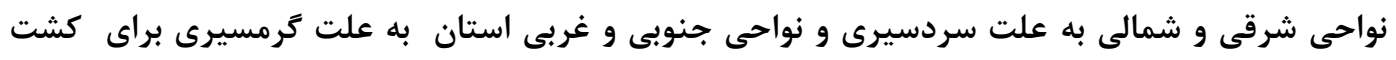
ذرت مناسب نبوده است.

كليد وازُكان: آزمون هتلينگ، آزمون T مشاهدهاى، عناصر اقليمى، ذرت، استان كرمانشاه.

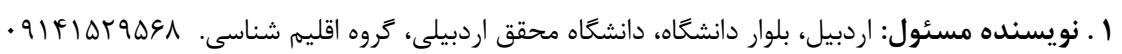


كشاورزى از مهمترين بخش هاى اقتصادى كشور براى رسيدن به توسعه پايدار است. آب و هوا مهمترين عاملى است كه تعيين كننده نوع گياه زراعى جهت كشت در هر منطقه مىباشد وانگ (Wang, 2014: 51). دوران

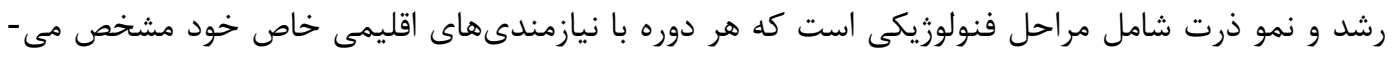

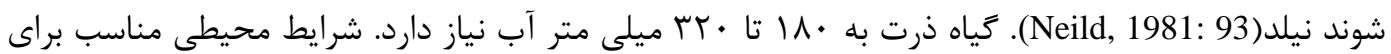

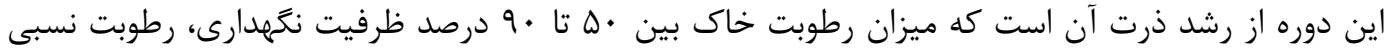

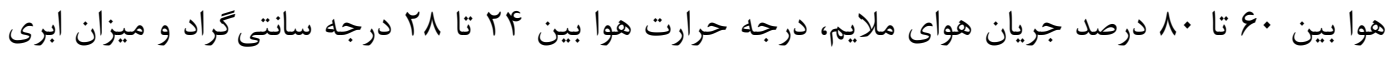

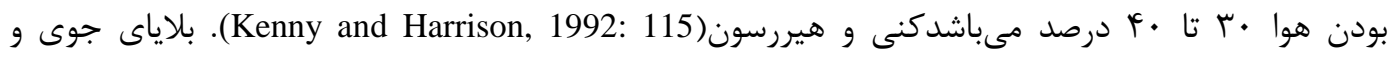

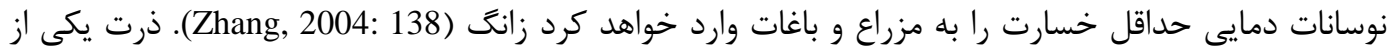

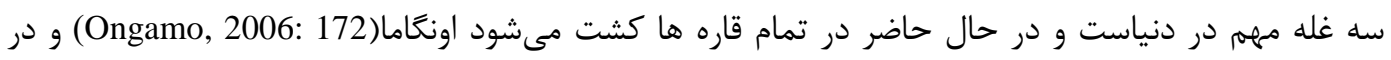
مناطقى كه باران و آبيارى به حد كافى باشد عملكرد قابل قبولى دارئ داردميكادور (Makadho, 1996: 149).

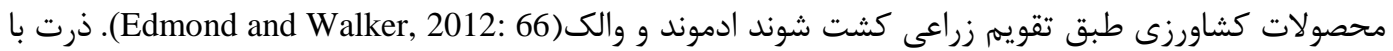

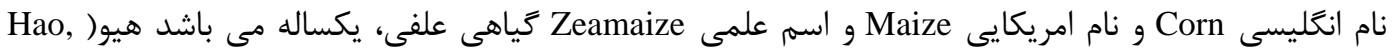

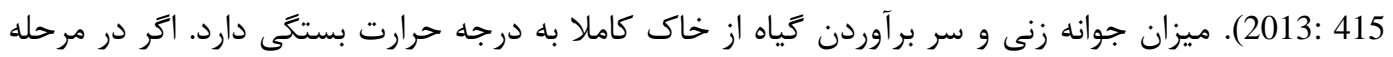

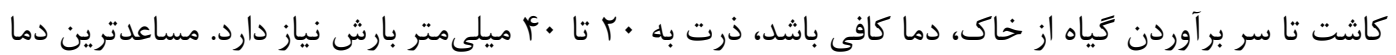

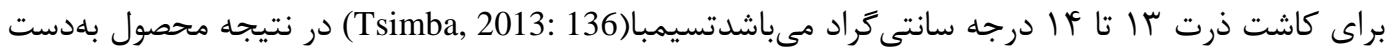

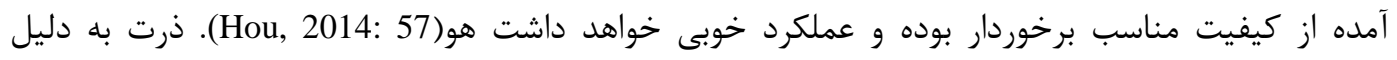

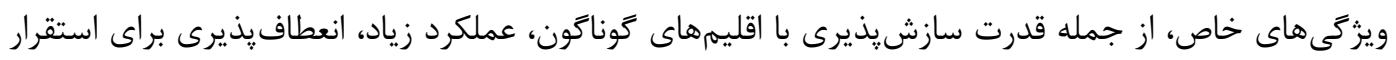
در تناوب زراعى مختلف و تنوع فرآوردههايى كه از آن به دست مى آيد در الكوى توليد كشاورزى دنيا از جائ جايكاه

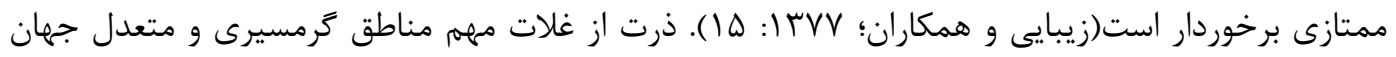

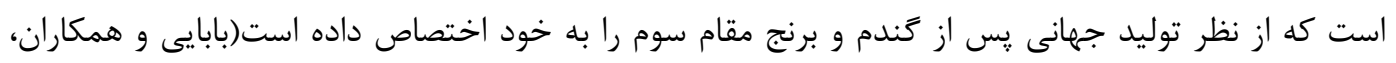

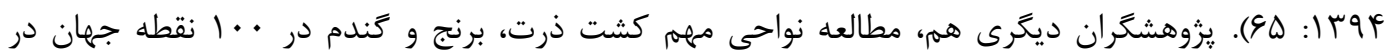

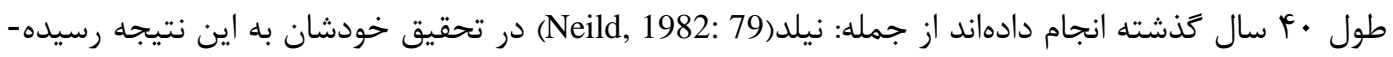

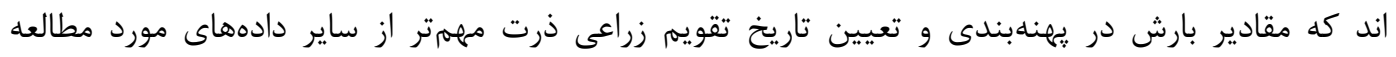

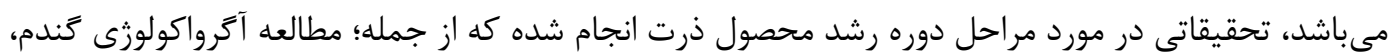

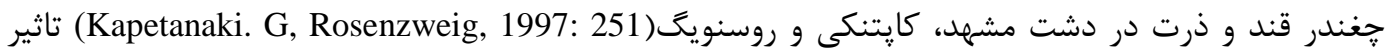

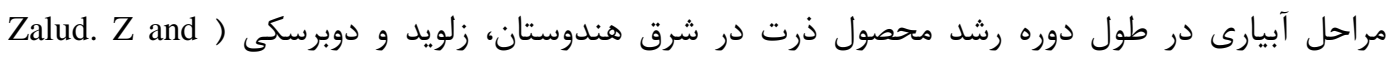

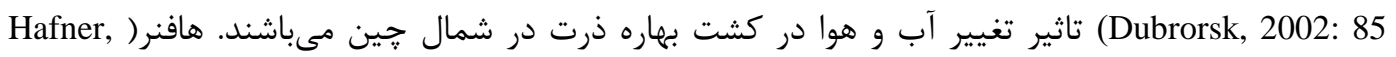

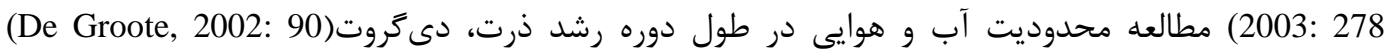

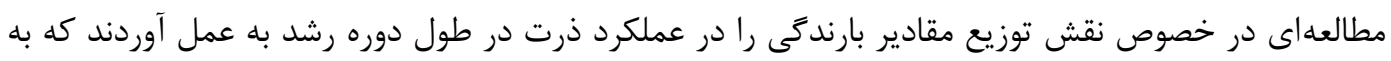

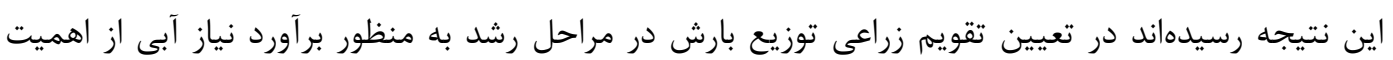

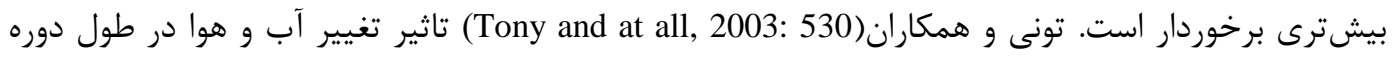




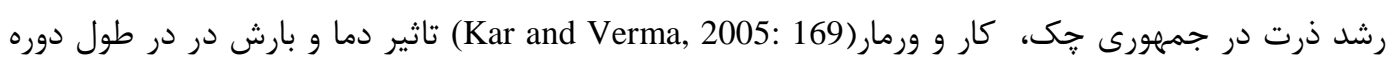
رشد ذرت و سوركوم، اونغاما(Ong'amo, 2006: 173) ارزيابى خطر خشكسالى در كشاورزى براساس منطق دارق

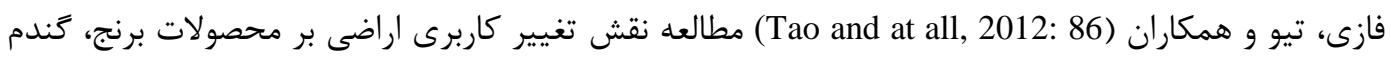

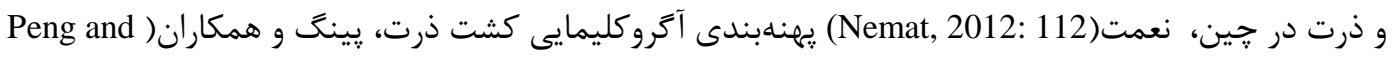
Holzkamper, بر (at all, 2013:532

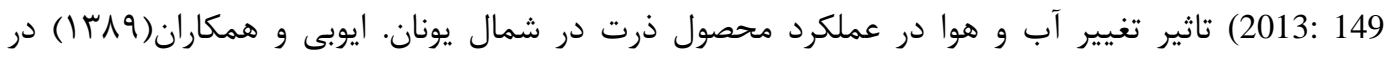

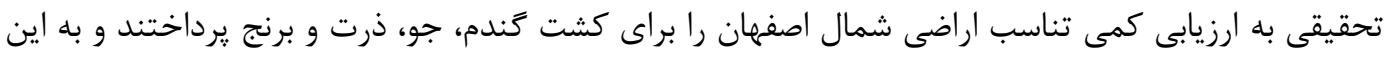

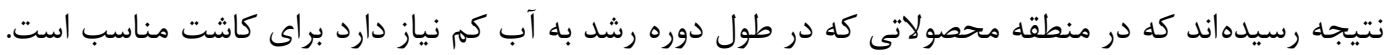

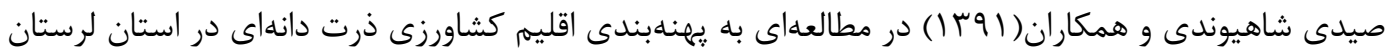

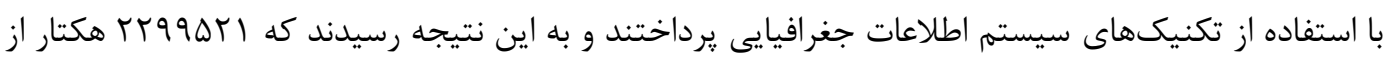

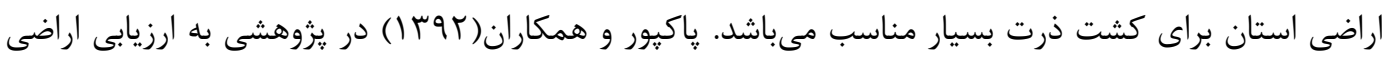
مستعد براى تعدادى از محصولات كشاورزى را در استان آذربايجان غربى با استفاده از دادههاى اقليمى و وعوامل

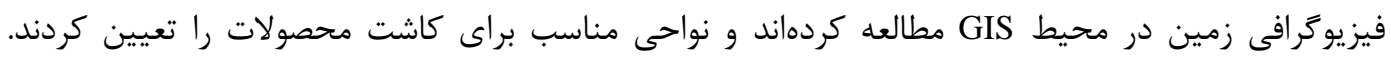

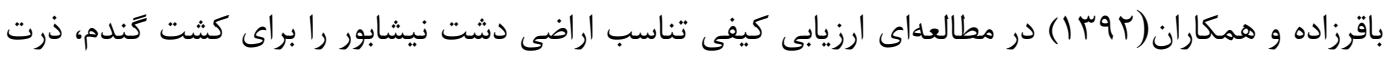

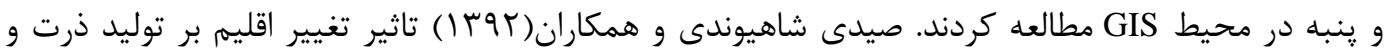
ارزيابى تغيير تاريخ كاشت را در شرايط آب و هواى مشهد مطالعه و به اين نتيجه رسيدهاند كه تغيير اقليم بر

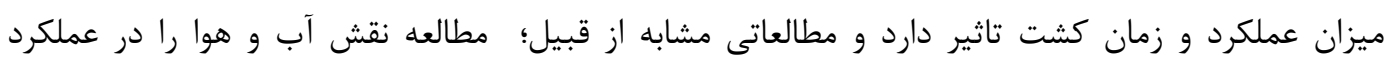

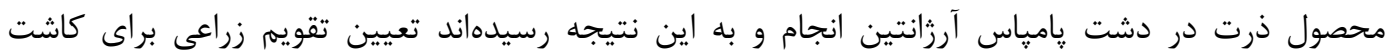

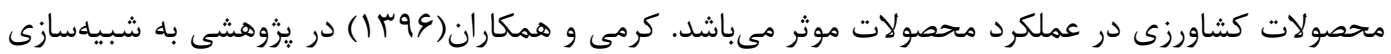

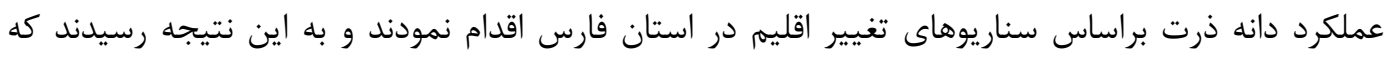

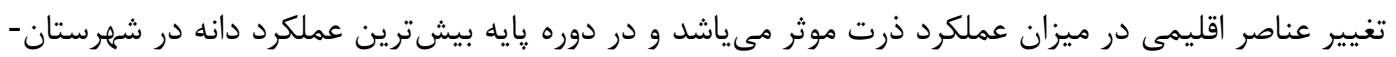

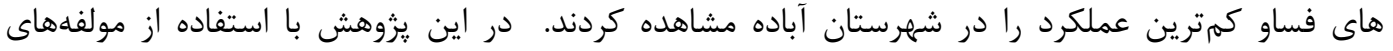

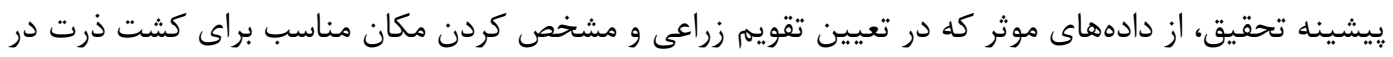

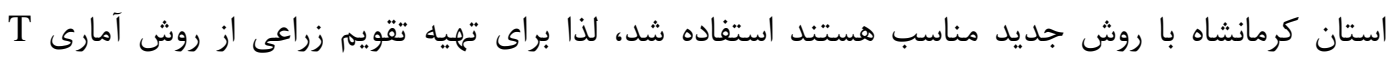

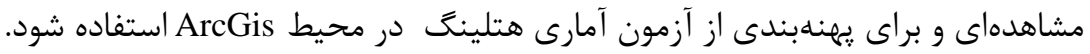

روش تحقيق محدوده و قلمرو يزوهش دوفي

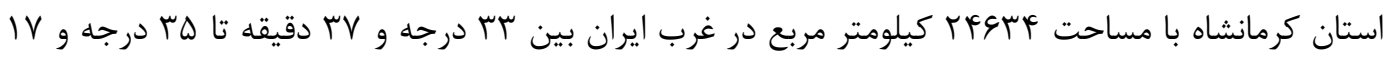

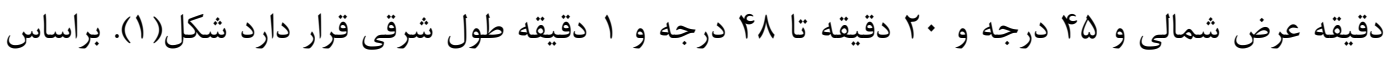

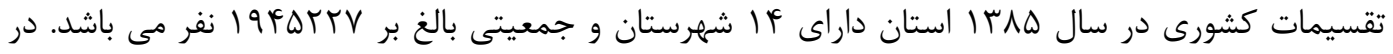

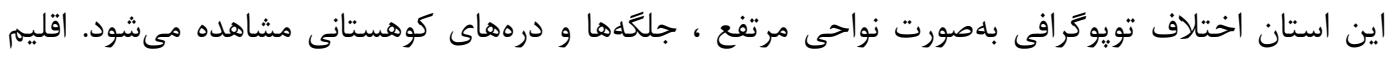

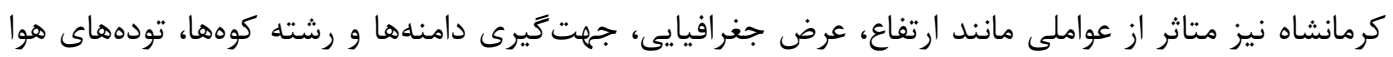


است. استان كرمانشاه را براساس دما، بارش و ناهموارى مىتوان به سه منطقه آب و هوايى تقسيم كرد: الف) منطقه سردسير: اين نوع آب و هوا در مناطق مرتفع استان مشاهده مىشود. بخشهاى انسان از شهرستانهاى

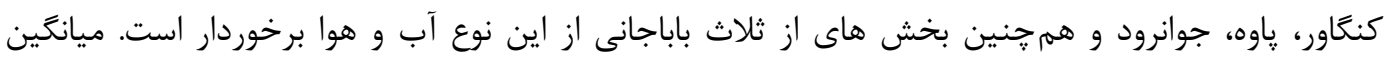

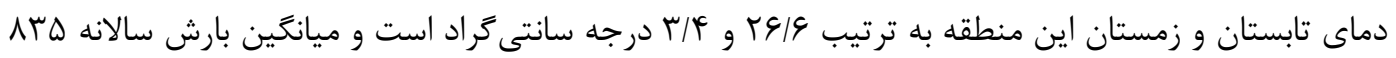

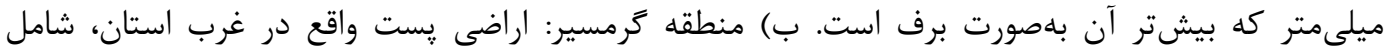

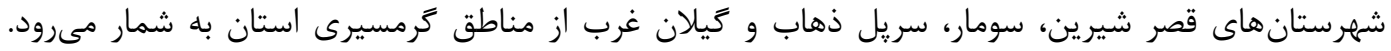

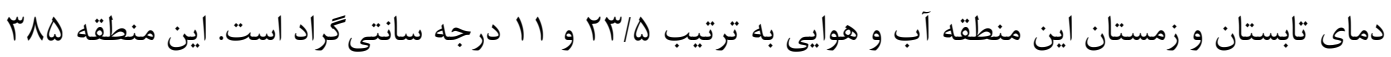

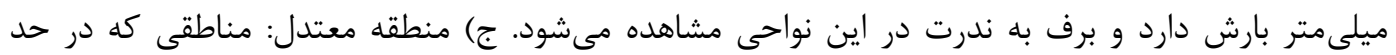

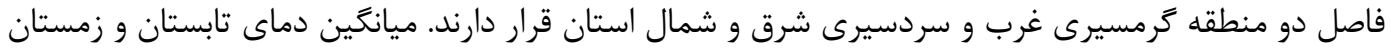

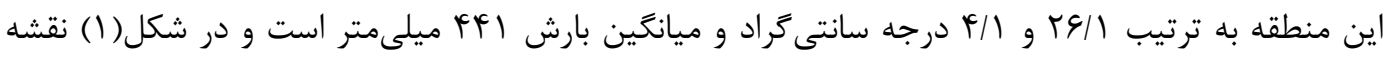
ارتفاعى استان كرمانشاه ارائه شده است.

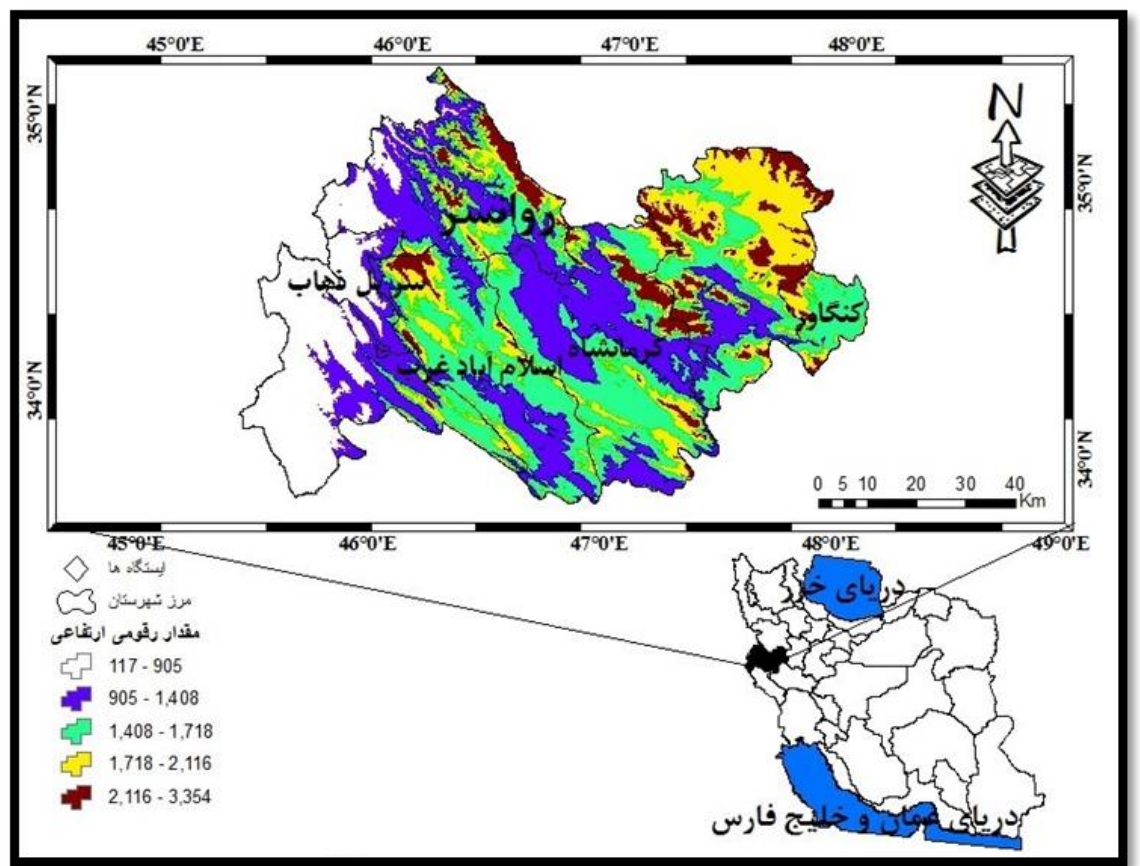

شكل(1). موقعيت جغرافياى و مقدار رقومى ار تفاعى ايستخاههاى مورد مطالعه در استان كرمانشاه

$$
\text { روش كار }
$$

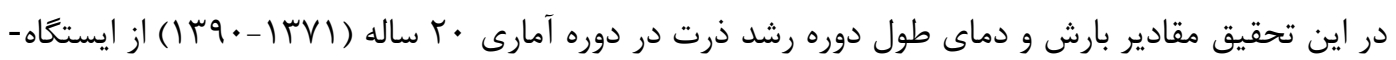

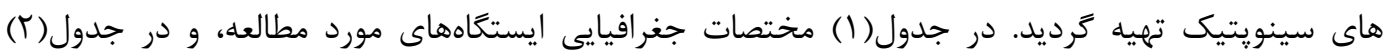
نيازهاى مطلوب اقليمى ذرت ارايه شده است. 
جدول (1). موقعيت ايستخًاههاى سينويتيك استان كرمانشاه

\begin{tabular}{|c|c|c|c|}
\hline عرض جغرافيايى & طول جغرافيايى & ارتفاع برحسب متر & نام ايستخًاه \\
\hline$r r^{\circ} r I^{\prime}$ & $q v^{\circ} \cdot q^{\prime}$ & $1 \pi 1 N / 9$ & كرمانشاه \\
\hline$r f^{0} \cdot V^{\prime}$ & $r \varphi^{\circ} r \Lambda^{\prime}$ & $\mid r \Lambda F / \Lambda$ & اسلام آباد \\
\hline$r F^{\circ} F \mu^{\prime}$ & $r \varphi^{\circ} r q^{\prime}$ & $1 \mathrm{rVq} / \mathrm{V}$ & روانسر \\
\hline$r r^{\circ} r V^{\prime}$ & $F \Delta^{\circ} \Delta Y^{\prime}$ & $\Delta F \Delta$ & سريل ذهاب \\
\hline$\mu \mu^{\circ} \Delta \cdot \cdot^{\prime}$ & $q V^{\circ} \cdot q^{\prime}$ & IFE. & كنغگاور \\
\hline
\end{tabular}

جدول (Y). نرمال اقليمى طول دوره رشد ذرت مآخذ(تسيمبا، سا+ץ)

\begin{tabular}{|c|c|c|c|c|c|c|}
\hline رنوبت & شارش شيرى & افشانى (مرداد) & $\begin{array}{c}\text { تارابر يشمين } \\
\text { (تيرش }\end{array}$ & بارش كل & بارش كاشت & بارش سالانه \\
\hline$\Delta T$ & 19. & $r \cdot \Delta$ & Tr. & $1 \cdot \Delta$ & $r r / Q$ & TTS \\
\hline رطوبت & دماى شيرى & دماى دوره & دماى تشكيل & دماى دوره & دماى دوره & دماى \\
\hline نسبى & شدن دانه & كردهافشانى & تارابريشمين & كل دهى & كاشت & سالانه(c) \\
\hline (درصد) & (شهريور) & (مرداد) & (تير) & (خرداد) & (ارديبهشت) & \\
\hline r & $T V / \Delta$ & r & $\Gamma / \Delta$ & $r \Delta$ & $1 \% / \Delta$ & $T V / \Delta$ \\
\hline
\end{tabular}

آزمون هتلينَ

با بهرهيرى از اين روش(r)، هدف آن است كه آيا مقدار

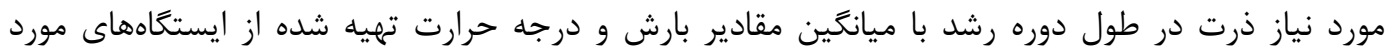

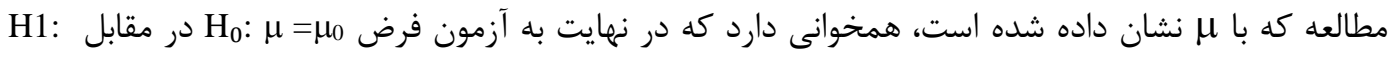


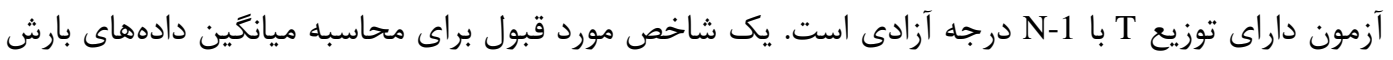
$T^{2}=n\left(\bar{x}-\mu_{0}\right), S^{-1}\left(\bar{x}-\mu_{0}\right) \leq \frac{p(n-1)}{n-p} F_{p, n-p(a)}$ و دما رابطه( (1) مىباشد. در رابطه( ()، T2 نشاندهنده شاخص آزمون هتلينغ است. N بيانكر حجم نمونه است (تعداد ماههاى طول دوره رشد ذرت است)،

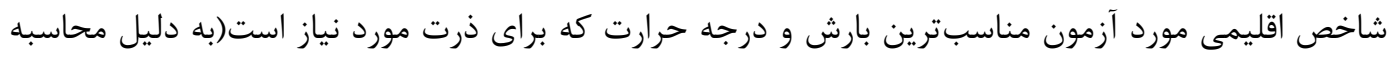

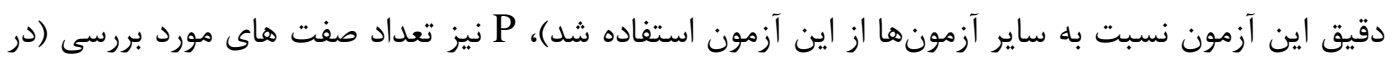

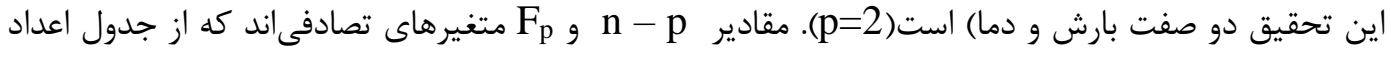

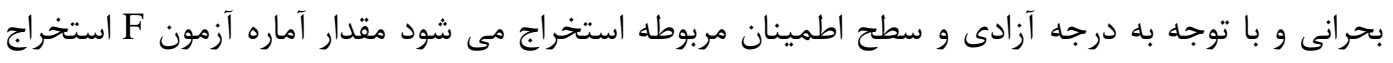

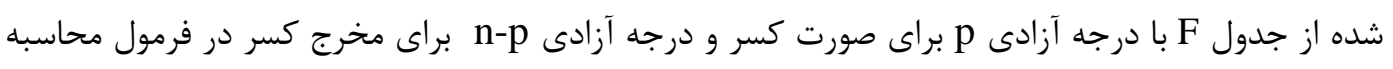


آماره F است. و S ماتريس كوواريانس نمونه ها است. براى محاسبه ماتريس كوواريانس، ابتدا ماتريس S بر اساس رابطه(r) محاسبه مى تردد.

$$
\mathrm{S}=\sqrt{ }(1 /(\mathrm{N}-1)) \sum(\mathrm{i}=1)^{\wedge} \mathrm{n}\left(\mathrm{x} \_\mathrm{i}-\mathrm{x}^{-}\right)^{\wedge} 2
$$

در رابطه(Y)، S بيانكر ماتريس داده هاى بارش و درجه حرارت يا ساير عناصر اقليمى است. معرف مقدار هر

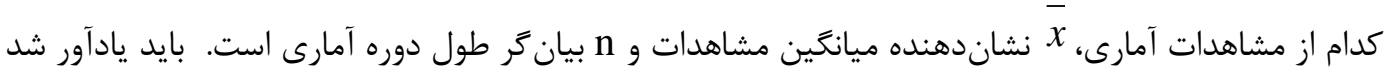
$\frac{p(n-1)}{n-p} F_{p, n-p(a)}$

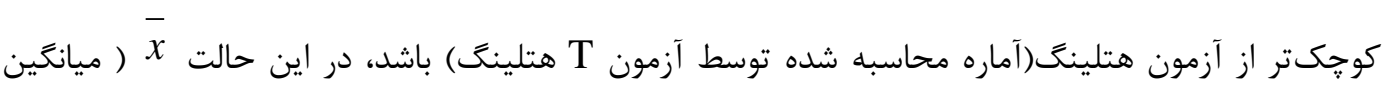

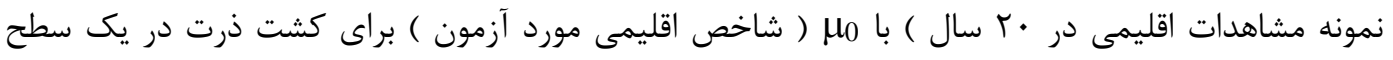

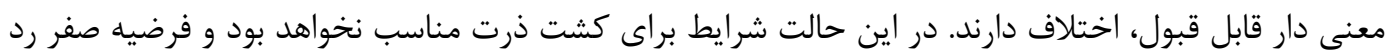
مىشود. در غير اين صورت، اتر مقادير اعداد بحرانى يا

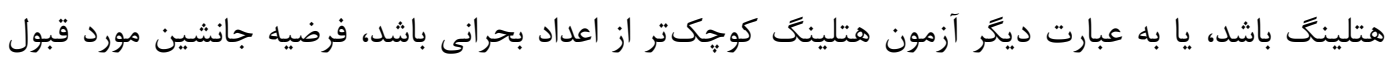

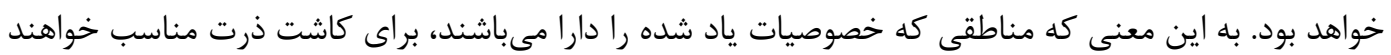

بود بريت(Bert, 2006: 182).

\section{آزمون Thاهدهاى}

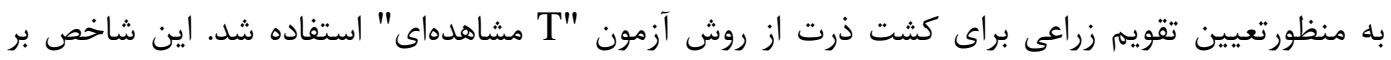

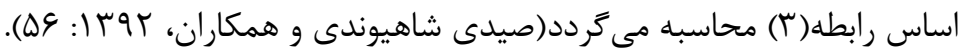
$t=\frac{\bar{x}-\mu_{0}}{\frac{s}{\sqrt{n}}}$

$$
\text { رابطه (广) }
$$

در رابطه(ب)، t نشان دهنده تى مشاهدهاى است.

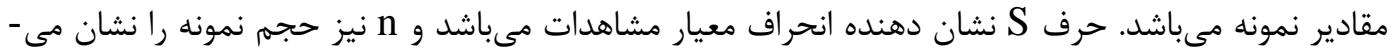

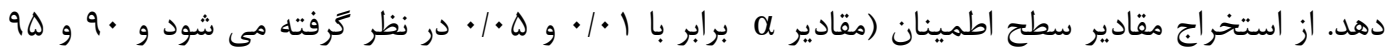

$$
\text { درصد) مى باشند. }
$$

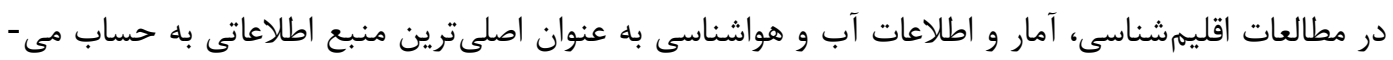
آيند. در اين يزوهش با انتخاب ايستخاههاى سينويتيك موجود در سطح دشت و استان، ميانگين دادهاتى

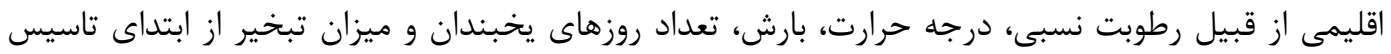

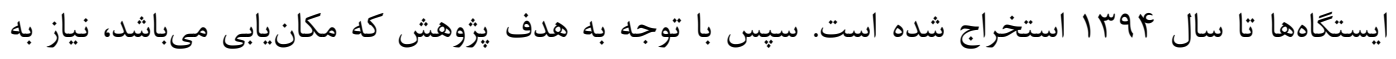

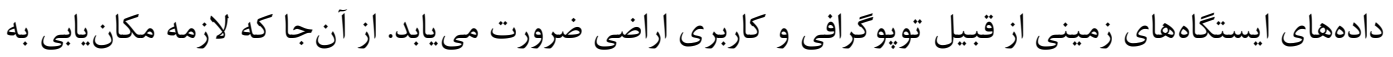

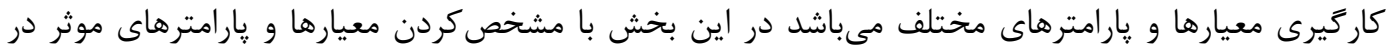



تعيين تقويم زراعى كاشت ذرت با استفاده از آزمون T مشاهدهاى و يهنهبندى...

كشت زيتون، اقدام به ارزيابى اهميت معيارها بر اساس تحليل سلسلهمراتبى با تعيين وزن براى هركدام از معيارها خواهد شد.

نتايج توزيع بارش: بارش به منظور تامين نياز آبى ذرت در طول مراحل رشد از اهميت زيادى برخوردار است شكل

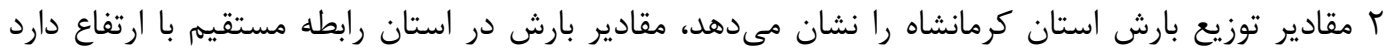

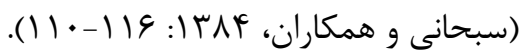

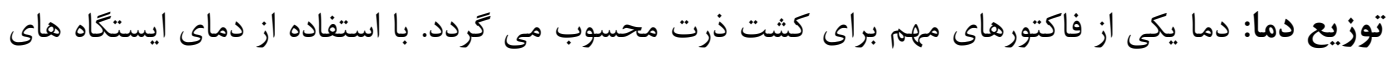

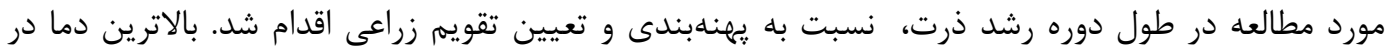
نواحى غربى و جنوب غربى(سريلذهاب و قصر شيرين) و كمترين دما در نواحى شرقى (سنقر، سطه، روانسر و

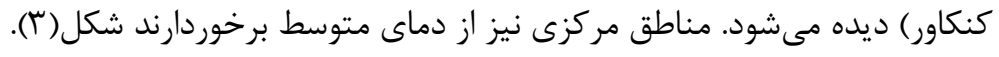

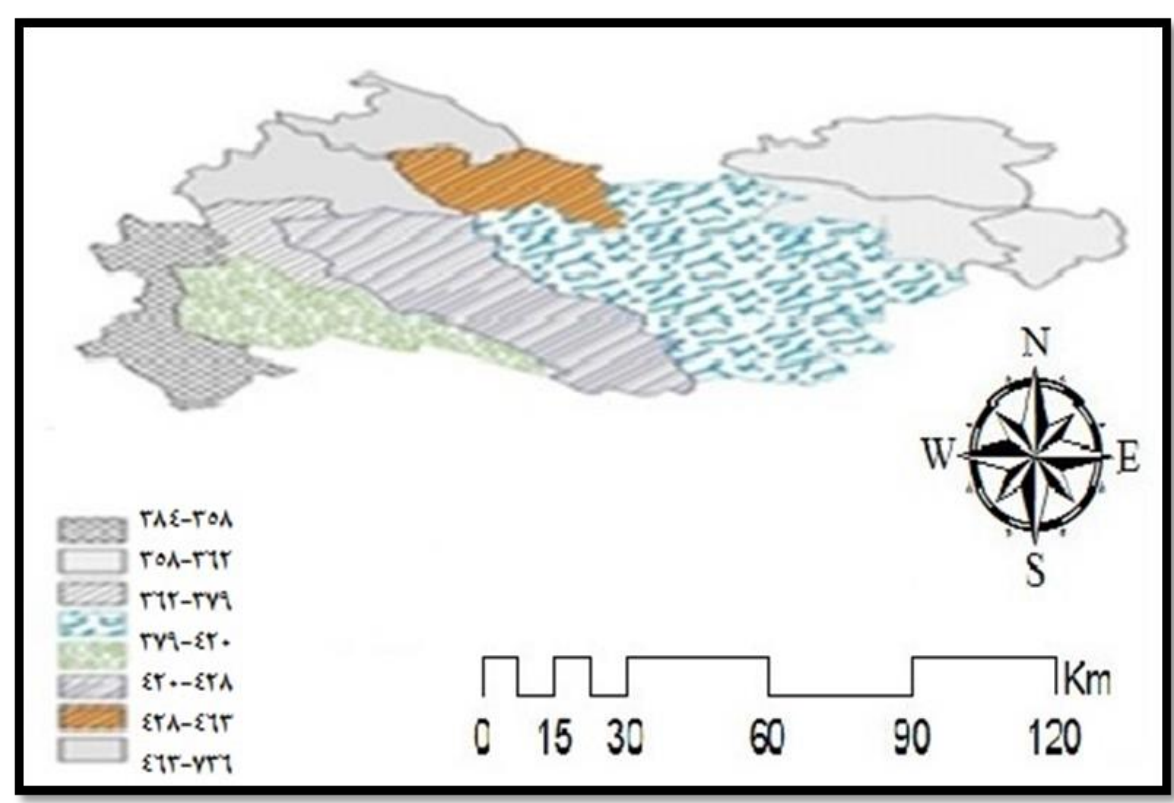

شكل(Y). توزيع مكانى بارش استان كرمانشاه 


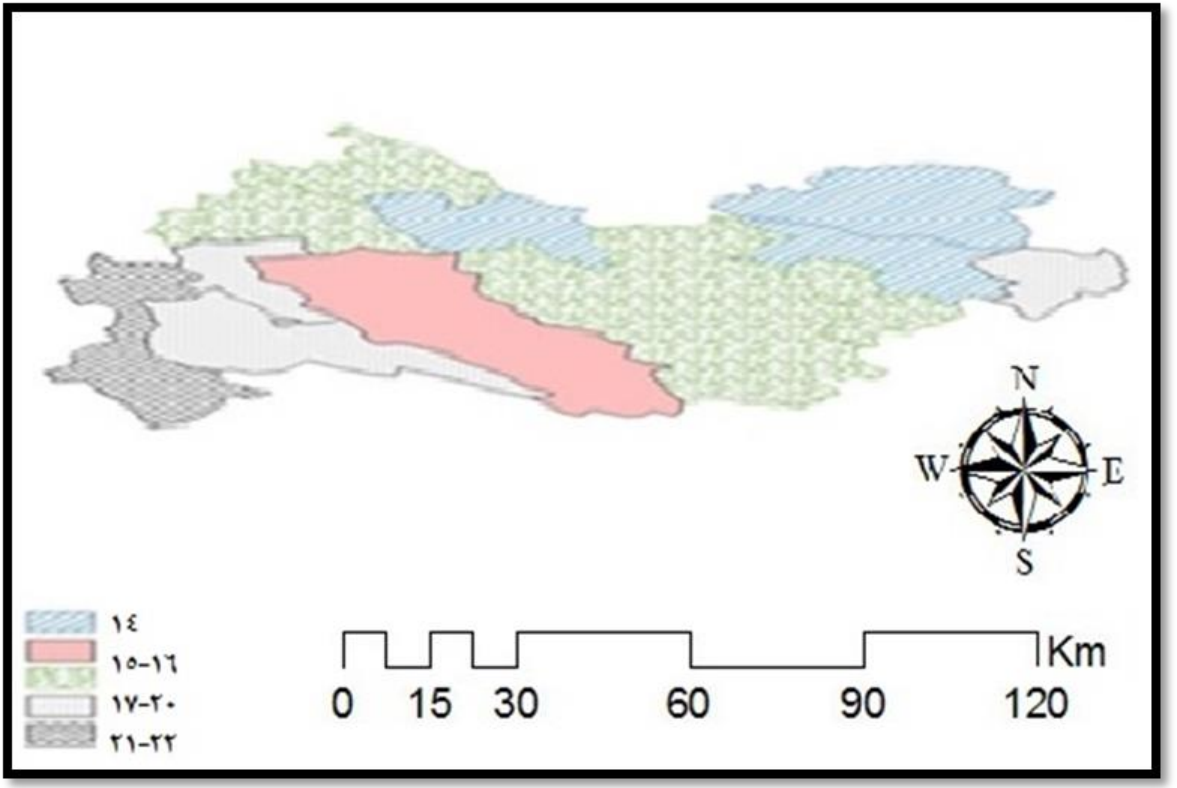

شكل(r). توزيع دماى استان كرمانشاه

آزمون هتلينَ: با تحليل آزمون هتلينگ، اراضى استان كرمانشاه براى كاشت ذرت به سه طبقابندى تقسيم شدند كه در شكل(f) نشان داده شده است.

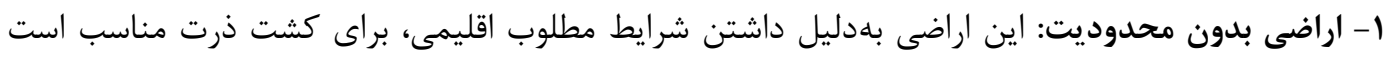

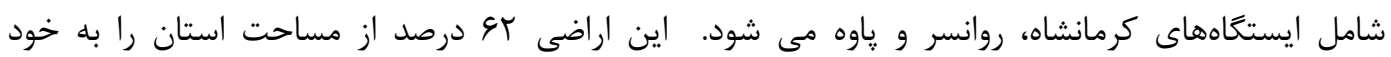

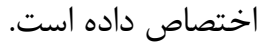
r- اراضى با محدوديت متوسط: اين اراضى شرايط نسبتاً ضعيفترى به مناطق محدوديت كم دارند،. ايستكاه

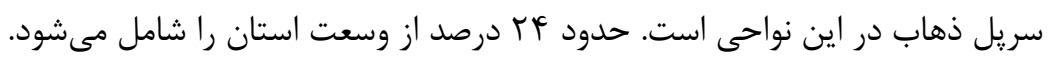

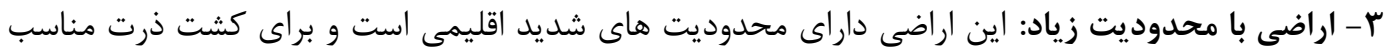

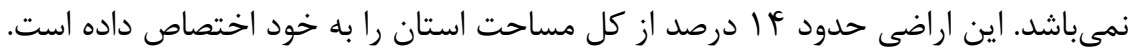




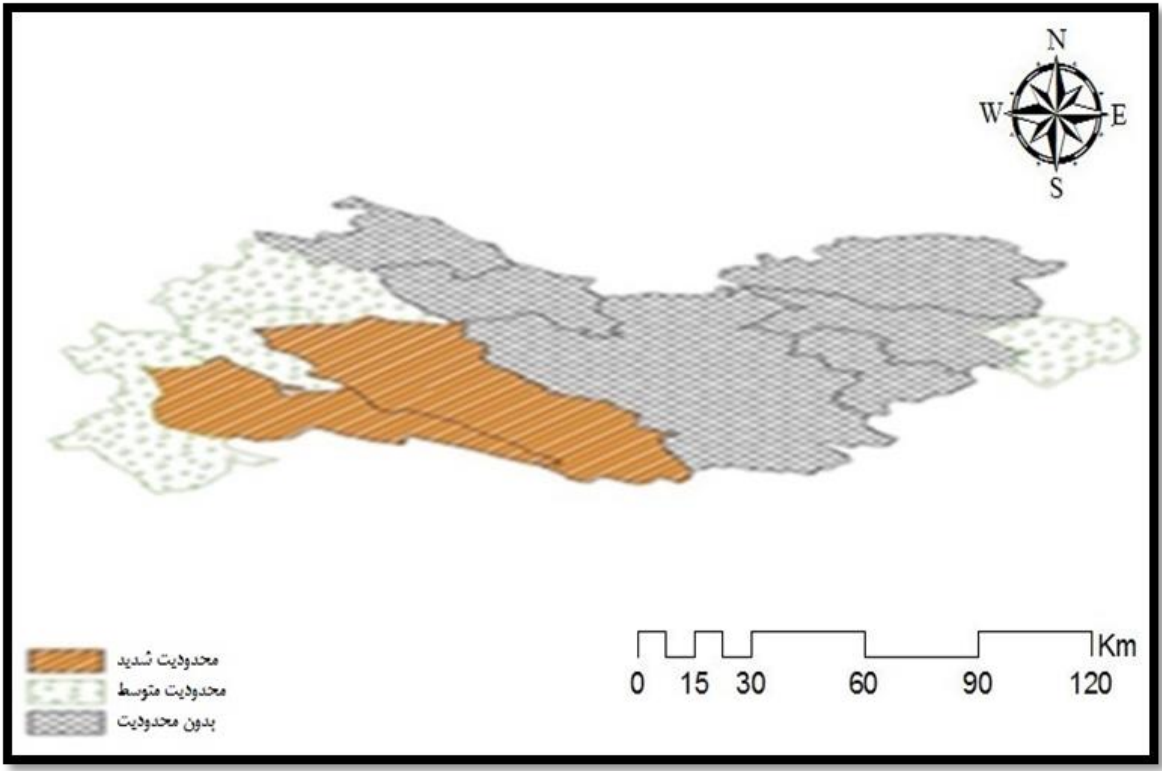

شكل(f). تحليل براساس آزمون هتلينَ

آزمون T مشاهدهاى: با تحليل دما و بارندگى ماههاى ارديبهشت، خرداد، تير، مرداد و شهريور، با آزمون "تى مشاهدهاى" تقويم زراعى كشت ذرت براى هر يك از ايستعاهها مشخص كرديد. در ايستخاههايى كه مقادير

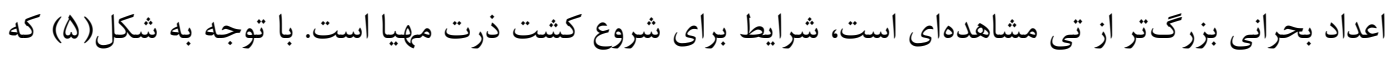
از تلفيق مقادير دما و بارش توسط آزمون تى مشاهدهاى بهدست آمد، منطقه مورد مطالعه به سه طبقه تقسيمم

ا- اراضى بدون محدوديت: اين اراضى به دليل دارا بودن شرايط بارشى و دماى مناسب در طول دوره رشد

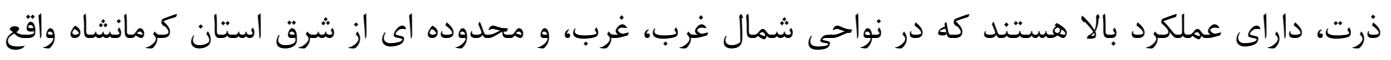
شده است. اين اراضى VV درصد از مساحت اين استان را شامل مىشود كه ايستخاههاى كنگًاور و سريل ذهاب در اين نواحى مىباشند. ץ- اراضى با محدوديت متوسط: اين اراضى داراى بارش و دماى متى متوسط است. كه نواحى مركزى استان را شامل مىشود از قبيل؛ كرمانشاه و روانسر، به دليل محدوديتهاى بارشى كمتر كه در اين ايستخاهها وجود

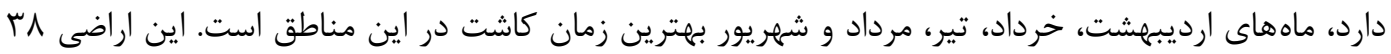

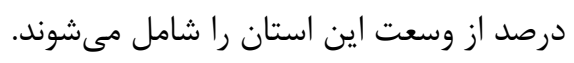
r - اراضى با محدوديت شديد: اين اراضى به دليل محدوديت بارشى و نوسانات دماى براى كشت ذرت ذرت مناسب

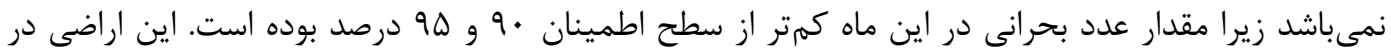

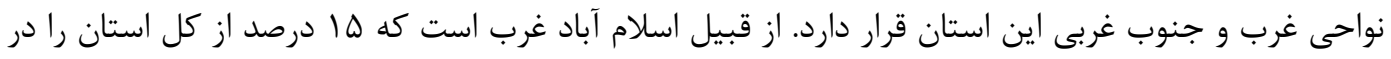
بر مى گيرد. 
نشريه تحقيقات كاربردى علوم جغر افيايى سال بيستم، شماره هV، تابستان

99

جدول(r). تقويم زراعى كشت ذرت با استفاده از آزمون تمى مشاهدهايى در استان كرمانشاه

\begin{tabular}{|c|c|c|}
\hline بررسى وضعيت اقليمى (دما و بارش) & طول دوره رشد ذرت & ايستخاهها \\
\hline 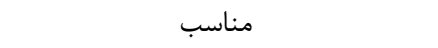 & جوانه زنى: 1 تا اب| ارديبهشت & \multirow{5}{*}{ كرمانشاه ، كنَّاور و } \\
\hline 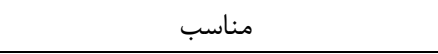 & كل دهى: 1 تا الr خرداد & \\
\hline 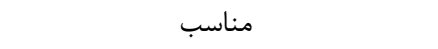 & تشكيل تار ابريشمى: 1 تا اس تير & \\
\hline 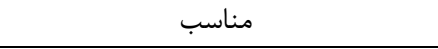 & ترده افشانى: 1 تا آ مرداد & \\
\hline 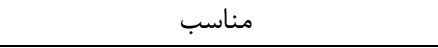 & شيرى شده و رسيدگى: تا اب شهريور & \\
\hline 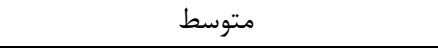 & جوانه زنى: اتا آ| ارديبهشت & \multirow{5}{*}{ 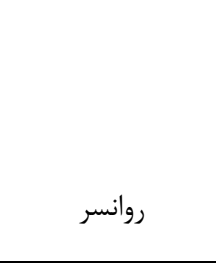 } \\
\hline 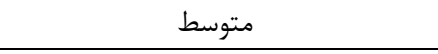 & كل دهى: اتا اب خرداد & \\
\hline 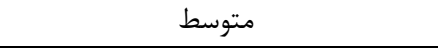 & تشكيل تار ابريشمى: اتا اس تير & \\
\hline 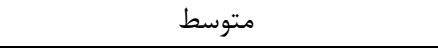 & ترده افشانى: اتا آب مرداد & \\
\hline 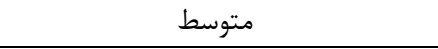 & شيرى شده و رسيدگى: ا تا آ شهريور & \\
\hline 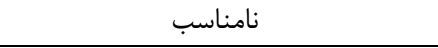 & جوانه زنى: اتا آ ارديبهشت & \multirow{5}{*}{ سريل ذهاب } \\
\hline 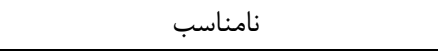 & كل دهى: اتا اس خرداد & \\
\hline 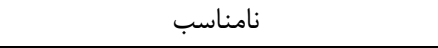 & تشكيل تار ابريشمى: 1 تا اس تير & \\
\hline 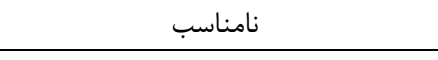 & ترده افشانى: 1 تا اس مرداد & \\
\hline 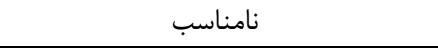 & شيرى شده و رسيدگى: ا تا اس شهريور & \\
\hline
\end{tabular}

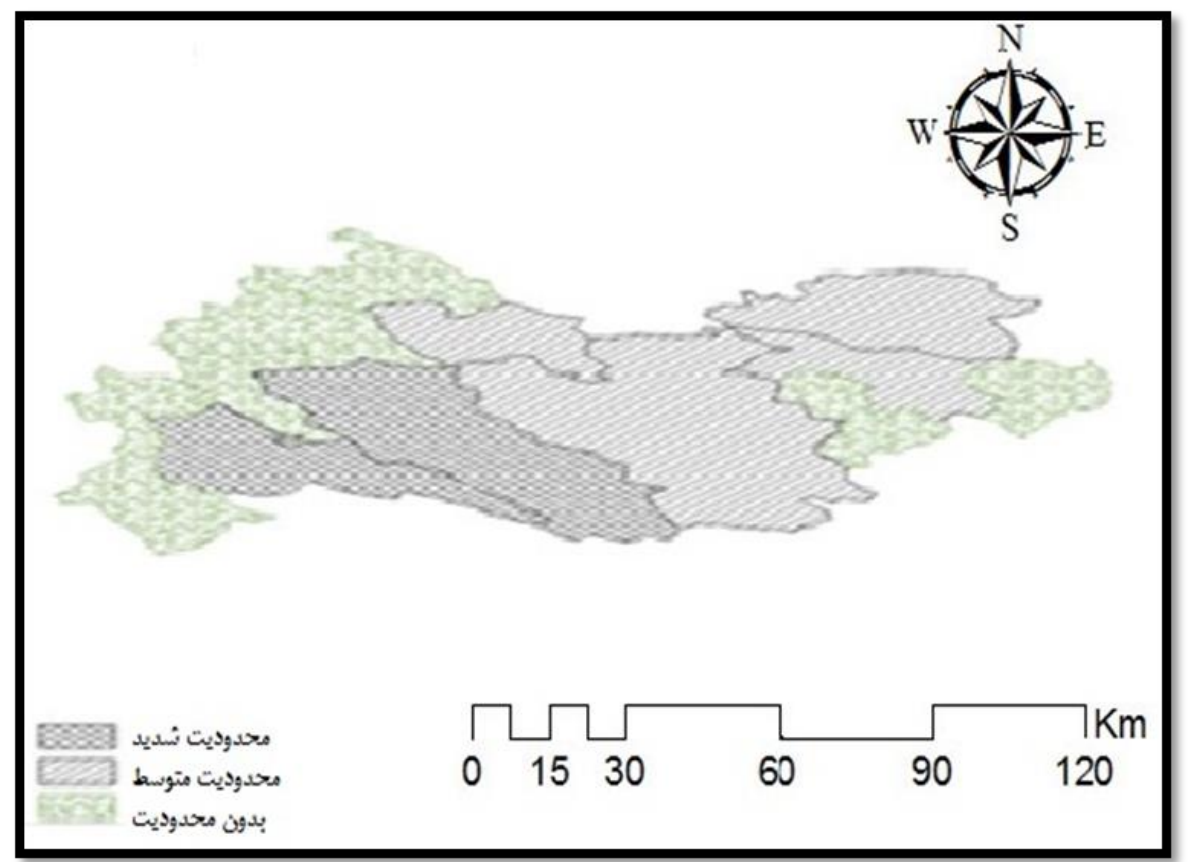

شكل(ه). تحليل براساس آزمون تى مشاهده 
هدف اين يزوهش تعيين تقويم زراعى كشت ذرت و شناسايى نواحى مناسب براى كشت در استان كرمانشاه

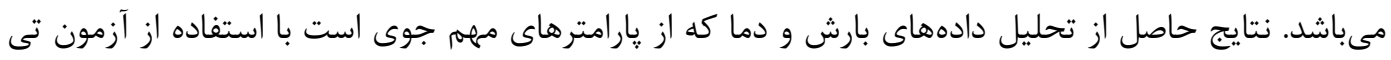

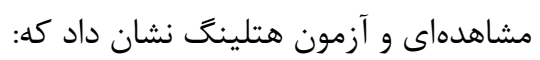

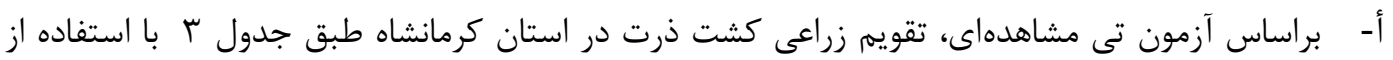

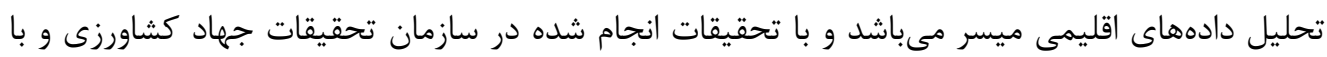

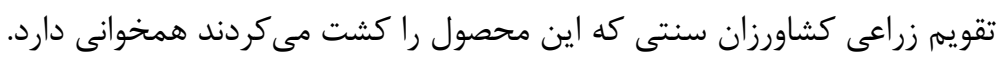

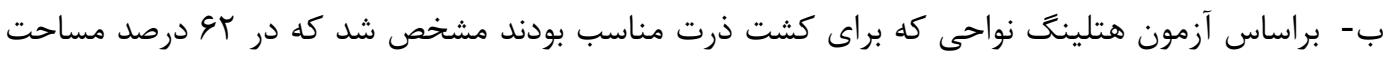

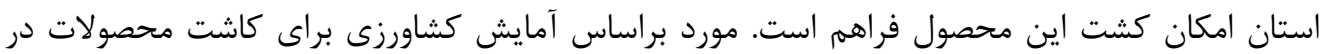

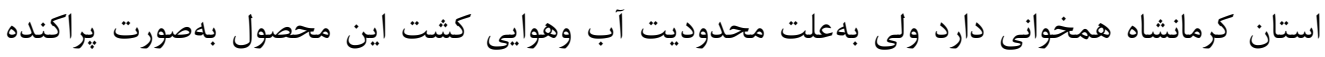
براساس تامين نياز آبى انجام مى شود.

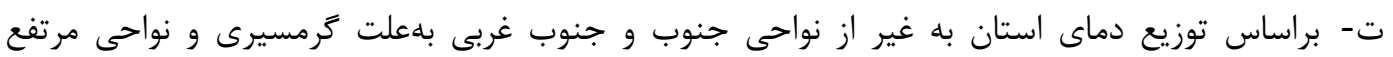
كوهستانى در شمال غرب و شمال شرق بهعلت افت دما در ساير نواحى شرايط براى كاشت ذائ ذرت برت مناسب است. ث- در استان كرمانشاه على رغم بارش مناسب سالانه، ولى توزيع بارش در طول دوره رشد ذرت نياز آبى آن را

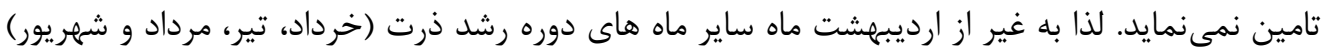
با كمبود بارش نسبت به نياز آبى مواجه است أرئ. ج- يشنهاد مى محصول بهمنظور صيانت از منابع آب هاى سطحى و زيرزمينى بلهورت محدود و در حر حد نياز استان توسط جهاد كشاورزى برنامهريزى گردد. ايوبى، شمس الله؛ كيوى، جواد؛ جلاليان، احمد و امينى، امير مظفر.( (9 بـا). ارزيابى كمى تناسب اراضى منطقه

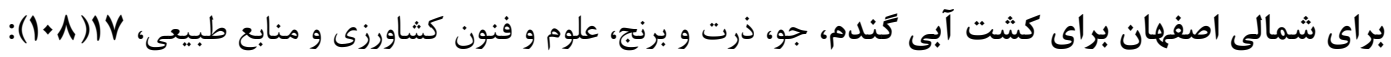
.1. $\Delta-11$.

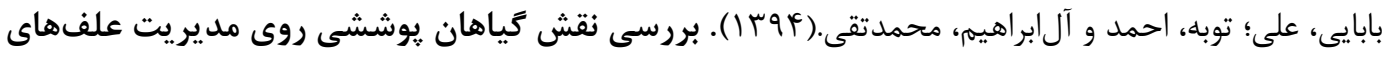

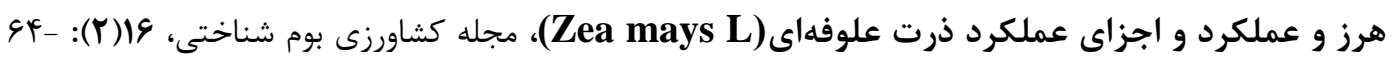

باقرزاده، حميد رضا ؛ باقرزاده، على و معين راد، حميد. (1 (1 ) ). ارزيابى كيفى تناسب اراضى دشت نيشابور

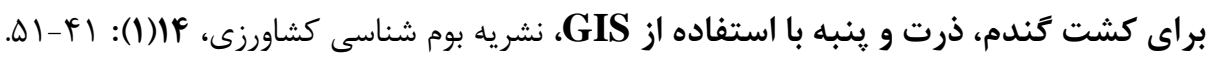




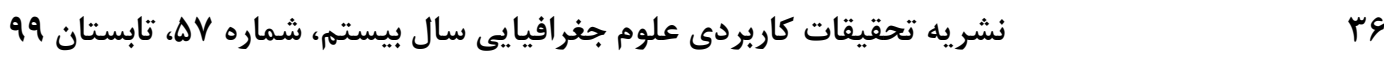

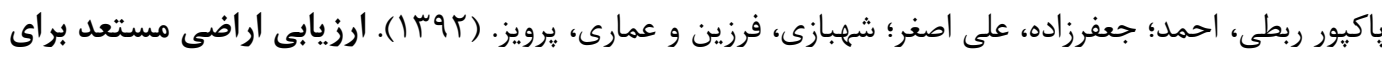

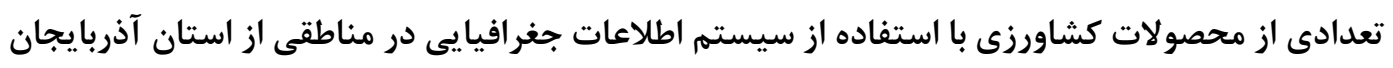

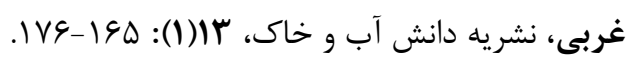

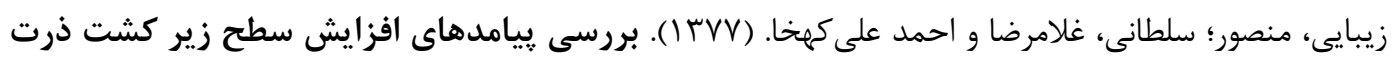

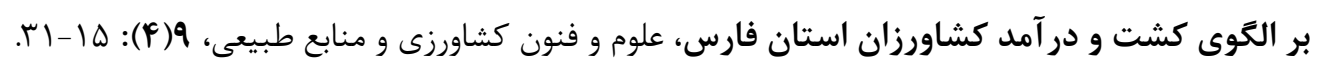

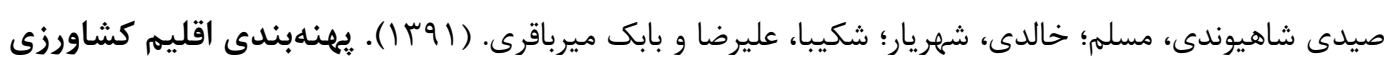

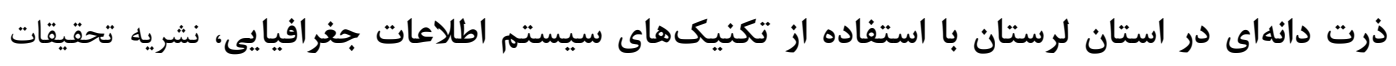

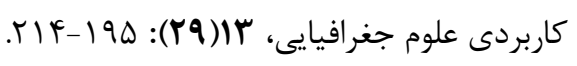

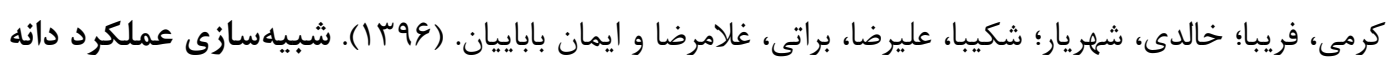

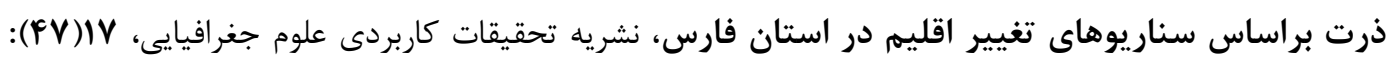
.VV-qr

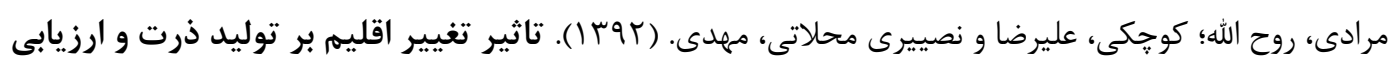

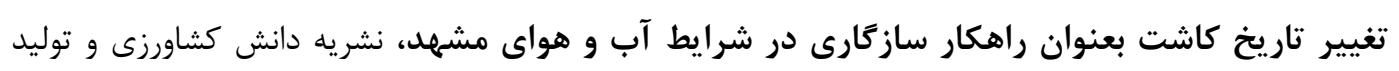

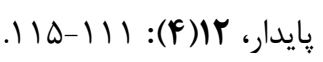

Basso. B, Bertocco. M, Sartori. L and Martin. E. (2007). Analyzing the effect of climate variabity on spatial pattern of yield in a maize - wheat - soybean, European journal of agronomy, 16: 82-91.

7- Bert, F. E. (2006). Climatic information and decision making in maize crop production system of the Argentinean Pampas, Agricultural systems, 88: 180-204.

De Groote. H. (2002). Maize yield losses from stemborers in Kenya. Insect Science and its Application, 22: 89-96.

Edmond Moeletsi, M and Walker, S. (2012). Asimple agroclimate index to delineate suitable growing areas for rainfed maize production in the Free State Province of South Africa, Agricultural and Forest Meteorology, 163: 63-70.

Gaiser, T. (2010). alidation and reliability of the EPIC to simulate maize production in small holder farming systems in tropical sub- humid West Africa and semi arid Brazil, Ecosystem and Environment, 135: 318-327.

Hafner. S. (2003). Trends in maize, rice and wheat yields for 100 nations over the past 40 years, Agricultural Ecosystem Environement, 97: 275-283.

Hao, F. (2013). Temporal rainfall pattern with water partitioning impacts on the maize yield infreeze-thaw zone, Journal of Hydrology, 486: 412-419.

Holzkamper. A. (2013). Identifying climatic limitions to grain maize yield using a suitability evaluation approach, Agricultural and Forest Meteorology, 168:149-159.

Hou. P. (2014). Temporal and spatial variation in accumulated temperature requirements of maize, Field Crops Research, 152:55-64.

Jones. P.G and Thornton. P.K. (2003). The potential impacts of climate change on maize production in Africa and Latin America in 2055. Global Environmental Change, 13: 51-59. 
Kapetanaki. G, Rosenzweig. C. (1997). Impact of climate change on maize yield incentral and northern Greece, Mitigationand Adaptation Strategies for Global Change, 1: 251-271.

Kar. G and Verma. H. N. (2005). Phenology based irrigation scheduling and determination of crop coefficient of winter maize in rice fallow of eastern India, Agricultural water management, 75: 169-183.

Kenny. G.J and Harrison. P.A. (1992). Thermal and moisture limits of grain maize in Europe, Climate Research climate, 2: 113-129.

Makadho, J. M. (1996), Potential effects of climate change on corn production in Zimbabwe, Climate Research, 6: 147-157.

Meza. F. J, Silva. D, Vigil. H. (2008). Climate change impacts on irrigated maize in Mediterranean climates, Agricultural Systems, 98:21-30.

Neild. R.E and Richman. N.E. (1981). Agroclimate normals for maize, Agricultural meterology, 24: 93-105.

Neild. R.E. (1982). Temperature and rainfall influences on the phonology and yield of grain sorghum and maize, Agricultural meterology, 27: 79-88.

Nemat allahy, E. (2012). Agro ecology zoning for wheat sugar beet and corn on the Mashad plain, The Egyptian Journal of Remote Sensing and Space Scienc, 15: 112-199. Ong'amo. G. O, Le Ru. B.P, Dupas. S, Moyal. P. (2006). Distribution, pest status and agro-climatic preferences of lepidopteran stem borers of maize in Kenya, Ann. soc. entomol. Fr, 42: 171-177.

Peng. L, Quan. Z, Ying. C and Jun. T. (2013). Assessing Maize Drought Hazard for Agricultural Areas Based on the Fuzzy Gamma Model. Journal of Integrative Agriculture, 12: 532-540.

Tao. F, Yokozawa. M, Xu. Y, Hayashi. Y, Zhang. Z. (2006). Climate changes and trends in phenology and yields of field crops in China, 1981-2000, Agric. Forest Meteorol, 138: $82-92$.

Tony. C, Hall. A. S and Wang. H. (2003). Landuse change in rice wheat and maize production in China, Agricultural Ecosystem Environement, 95: 523-536.

Tsimba, R. (2013). The effect of planting date maize grain yield and yield components, Field Crops Research, 150: 135-144.

Waha. K, Muller. C, Rolinski. S. (2013). Separate and combined effect of temperature and precipitation change on maize yields in sub- Saharan Africa, Global and planetary change, 106: 12-27.

Wang. X. (2014). Divergence of climate impacts on maize yield in Northeast China, Agriculture, Ecosystems ND environment, 196: 51-58.

Zalud. Z and Dubrorsky. M. (2002). Modeling climate change impact on maize growth and development in the Czeeh Republic, Appl. Climatology, 72: 85-102.

Zhang. J. (2004). Risk assessment of drought disaster in the maize growing region of songliao plain China, Agricultural Ecosystem Environement, 102: 133-153.

Zhao. J, (2015). Effect of climate change on cultivation pattern of spring maize and its climatic suitability in Northeast China, Agricultural, Ecosystem and Environment, $45,120-128$. 